DOI https://doi.org/10.30525/978-9934-26-073-5-1-31

\title{
ТРАНСФОРМАЦІЯ АРХЕТИПУ ЖІНКИ У ЗБІРЦІ ОПОВІДАНЬ «ЛЕГЕНДИ СТАРОКИЇВСЬКІ» НАТАЛЕНИ КОРОЛЕВОЇ
}

\author{
Ковальчук Ю. А. \\ аспірантка III року навчання \\ кафедри української та зарубіжної літератур \\ Житомирського державного університету імені Івана Франка \\ м. Житомир, Украӥна
}

Архетип жінки завжди був актуальним в українській літературі. Дослідження трансформації образу жінки фокусує увагу науковців і донині.

Цікавим є висвітлення названої проблематики на прикладі маловідомих або недостатньо розроблених в Україні текстів [10, с. 272].

До таких текстів належить збірка оповідань «Легенди старокиївські» Наталени Королевої (не менш цікавої та неординарної авторки української еміграції, про творчість якої заговорили лише в кінці XX ст.).

«Легенди старокиївські» - це синтез поглядів та переконань авторки щодо ролі жінки у суспільстві. Хоча оповідання сюжетно не пов'язані між собою і дана тема не є центральною у збірці, провівши глибоке дослідження міфологічних та історичних образів, чітко простежується позиція Наталени Королевої щодо жінки як до першооснови життя, переходу цивілізації від патріархату до матріархату, а також гендерної рівності.

Наталена Королева - «оригінальна іноземка» в українській літературі початку XX ст., письменниця-інтелектуалка, яка раціоналізму і матеріалізму цієї доби чітко протиставила ідеалізм і моральність. Ї̈̈ естетична свідомість, загрунтована у французьку християнську філософію і німецький романтизм, демонструє парадигму європейської духовності, у якій згармонізовані індивідуальні «я», активність і віра (зокрема жіночого «я»). Така окцидентальність авторки зумовлює увагу до епох Античності, Середньовіччя, Бароко, полілог із європейською й українською історією, культурою, духовністю [5].

Героїні збірки не $є$ «простими» людьми. Це міфологічні істоти, боги, відомі історичні постаті, які змінили хід історії. Наталена Королева не зверталася до сільського життя, адже вона його не знала. Вводячи у свою збірку «вищий» і «найвищий» шар населення, авторка показувала 
еволюцію жіночої психіки по відношенню до самої себе та різних позицій чоловічого бачення до жіноцтва.

Героями ії творів, крім античних і міфологічних образів (меви, мавки, русалки, амазонки), ставали і видатні історичні постаті (княгиня Ольга, князівна Анна Ярославівна, мати римського імператора Костянтина I Хлора імператриця Олена, ймовірна позашлюбна донька Володимира Людмила, сестра Либідь тощо). Часто Наталена Королева зверталася до образу жінки у іiі різних іпостасях: «жінки-Матері», «жінки-воїна», «жінки-борця», «жінки-коханої», «жінки-Землі», «жінки-громадянина» тощо. На деяких із них письменниця інтерпретувала саму себе. Аналізуючи іiї творчість, часто можна простежити погляди головних героїнь, притаманні самій авторці [5].

У наш час потрібне усвідомлення людством необхідності нового підходу до цінності жінки. Саме це і започатковує авторка у своїй творчості.

Архетипи жінок у «Легендах старокиївських» можна поділити на декілька груп: античні образи (Артеміда, Афродіте, Дафне, Дріада, Еос, Ізіда, Лосна, Марена, Мітра, Мокош, Парки, Пітія, Полігімнія тощо), історичні постаті (Анна Царгородська, Ольга, Олена, Марія, Магдалена, Рогніда Рогволодівна тощо), загальні образ (августа - титул дружини римського імператора, архонтиса - княгиня, вища службова особа, гетера - незалежна освічена жінка, гітана - іспанська циганка, зоста дівчина, мева - чайка, русалка, нава - русалка, хова - нянька тощо).

У образах богинь, історичних постатей-жінок авторка поєднувала розум, силу, винахідливість, розсудливість, хитрість та відданість [5].

Трансформація образу жінки починається від «жінки-рабині» до «жінки-воїна», «жінки-Матері», «жінки-Землі», «жінки-партнера».

Ще 3 античного світу для чоловіків жінка вважалась лише здобиччю, яка повинна підкорятися: «Жінка $є$ тільки здобич, а радість від неї в тім, що можна показати на ній свою силу й волю. Бо ж вона послухає у всьому кожного мужа» («Опойний дим») [8, с. 9].

Пізніше з'являються войовничі амазонки, які повністю відгородилися від чоловіків і намагалися створити власний устрій. Які билися 3 чоловіками і уже з того часу почали зауважувати про рівноправність, але все-таки мали жіноче лагідне начало: «Жалієш його... Бачу, що під войовничим панцирем маєш прецінь жіноче серце. А коли так, то кинь меч, а натомість подбай про веретено й колиску. $\mathrm{Hi}$, ні, не говори: він вже переміг тебе!» («Таврійська бай») [8, с. 32].

Жіноче материнське серце яскраво змальоване і у іншому оповіданні збірки - «Скитський скарб», де мати заради добробуту своїх дітей готова 
на все, навіть не усвідомлюючи того, що цим занапастила себе і своїх нащадків: «Це - вогонь, що у серці земному палає! - думкою Лартиною лише... I, як серце тепле тварині, дає дихання життя землі... Ой, як добре дати це дітям моїм!.. А золото сяє... червонавими вогниками миготить немов кров’ю побризкане, по новій крові тужить... Але не почуває себе покинутою Ларата. Вона - жінка! Тож доля ії відмінна від долі мужів...» [8, c. 144, 145].

Жіка-матір завжди готова до самопожертви заради свого чада, вона буде битися до смерті: «Дитинка прокинулась, плаче й рученятами до матусі тягнеться. Телерсис - до неї: мужа не чує, про власну журу забула. I раптом в покірливій матері прокидається колишня амазонка...» («Володимирове срібло») [8, с. 54].

Та для кожної людини одним 3 головних образів у житті є Земля, Земля-годувальниця (ще один жіночий архетип - Земля - Життя): «Його покликала Земля - нестримано-приваблива коханка. Відрад зрозумів: переквіла й обсипалась яблуневим квіттям весняна пора його юності 3 бурями й мріями... Відрад почув себе доспілим мужем, серце якого заручилось на добру і злу долю 3 рідною Землею» («На Делосі») $[8$, c. 171$]$.

Притаманні жіночі риси ревнощів та заздрості теж присутні у збірці «Легенди старокиївські», зокрема яскраво змальований любовний трикутник у оповіданні «На Делосі» (Арга - Опіда - Відрад).

Але все-таки краса, сила, розум, хитрість, підступність, владність, помсту - уособлює ключова жіноча постать збірки - княгиня Ольга: «I Анастасія зауважила, що «руська зоста» називала свою княгиню Ельгу - Ольгою. Це наймення видалось Анастасії таким милим i граціозно дівочим, що стурбовані думки несподівано прошило іскроюпустункою: - Такої красуні Ольги не посмів би вхопити в свої обійми ані сам Базилевс, як щойно спробував був затримати іiі, Анастасію, Юстиніан... Бо ж здавалось: лише зсуне Ельга свої широкі брови, то враз загримить грім, як за часів давньовікового Зевса. А як гляне обурено, то блисками сипнуть іï сталеві, сірі, як у мисливського сокола, очі. А довгі, темні, не сивиною, а перлами пересипані коси напружаться гадами та стануть в оборону княгині» («Путь спасіння») [8, с. 83].

Наталена Королева незримо обгрунтувала гендерний підхід у своїй збірці оповідань «Легенди старокиївські». За допомогою аналізу механізмів входження і існування жінок у культурному просторі України другої половини XX століття (через інтерпретовані жіночі образи античності та середньовіччя), довела, що репрезентація жінок в офіційній культурі була залежною від усталених патріархальних традицій 
суспільства і відзначалась гендерною асиметрією. Представництво жінок меншою мірою цінувалося у будь-яких соціальних інститутах 3 найдавніших часів порівняно із чоловіками, що в цілому доводило не відповідність потенційним можливостям і реальному внеску жіноцтва у формування суспільних цінностей. За допомогою інтерпретованих жіночих образів у своїй легендарній збірці «Легенди старокиївські» показала домінуючу сторону жіноцтва [5]. А також чітко доводила, що жінка - це не рабиня, а партнер для чоловіка, невід'ємна складова для чоловічого існування (образ князя Володимира та княгині у оповіданні «Кирило Кожум'яка »).

\section{Література:}

1. Антофійчук Володимир. Євангельський контекст у творчості Наталени Королевої // Слово й час. № 8, 2000. С. 36-45.

2. Вайнтруб I. Лицарі степів: «Словесний портрет» сакральної культури скіфської цивілізації // Людина і світ, 1998. № 10. С. 43-48.

3. Видатні постаті в історії України (IX - XIX ст.): короткі біографічні нариси. Історичні та художні портрети: Довід. вид. / В. І. Гусєв, В. П. Дрожжин, Ю. О. Колітцев, О. Г. Сокирко, В. І. Червінський. Київ: Вища школа, 2002. 359 с.

4. Ірина Голубовська. Виплекані мрією і любов’ю // Слово і час. № 11, 2002. С. 41-45.

5. Ковальчук Ю. А. Інтерпретація жіночих образів у збірці оповідань «Легенди старокиївські» Наталени Королевої [Електронний ресурс] / Режим доступу: http://www.sci-notes.mgu.od.ua/archive/v32/15.pdf

6. Королева Н. Предок: Історичні повісті. Легенди старокиївські / Упорядн., автор післямови та приміток О. В. Мишанич. К, 1991. 334с.

7. Мишанич О. Дивосвіти Наталени Королевої // Королева Н. Предок. K., 1991.

8. Наталена Королева. Легенди старокиївські / Ред. Н.В. Сойко. К.: Школа, 2006. 256 с.

9. Скорина Л. «Гомін та відгомін»: дискурс інтертекстуальності в українській літературі 1920-х років: Монографія. Черкаси: Брама-Україна, 2019. 704 с.

10. Смольницька О. О. Образ фатальної жінки і архетип великої матері у творчості членів Нью- Йоркської групи: фольклорноміфологічний контекст // «Молодий вчений». № 9, 2017. С. 272-279. 